\title{
KEBERPIHAKAN REGULASI PERTANAHAN TERHADAP HAK MASYARAKAT ADAT (STUDI KASUS SENGKETA TANAH ADAT DI DESA KUBUTAMBAHAN, KECAMATAN KUBUTAMBAHAN, KABUPATEN BULELENG)
}

\author{
Ratna Artha Windari \\ Jurusan PPKn, Fakultas IImu Sosial, Universitas Pendidikan Ganesha \\ Singaraja, Indonesia \\ e-mail: ratna_windari@yahoo.co.id
}

\begin{abstract}
Abstrak
Penelitian ini bertujuan untuk mengetahui faktor-faktor yang melatarbelakangi terjadinya sengketa tanah adat di Desa Kubutambahan dan bentuk keberpihakan regulasi pertanahan terhadap hak masyarakat adat; serta peran desa pakraman dalam mengatasi sengketa tanah adat. Penelitian menggunakan pendekatan kualitatif. Hasil penelitian menunjukkan bahwa: 1) Faktor penyebab terjadinya sengketa tanah yaitu: Adanya kesimpangsiuran silsilah keluarga; Proses administrasi pertanahan yang kurang jelas; Kurangnya pemahaman akan sistem pewarisan adat; dan Kurangnya pemahaman masyarakat tentang regulasi pertanahan nasional, (2) Bentuk keberpihakan regulasi nasional yaitu: Adanya perlindungan hukum dan hak asasi manusia terhadap Identitas budaya masyarakat hukum adat, termasuk hak atas tanah ulayat; Adanya pengakuan wewenang desa dalam mengatur dan mengurus kepentingan masyarakat setempat berdasarkan asal usul dan adat istiadat setempat; Hukum adat dijadikan dasar berlakunya hukum agraria, dan adanya perlindungan serta pengakuan terhadap hak milik atas tanah Desa Adat. (3) Bentuk peran Desa Pakraman dalam mengatasi konflik pertanahan yakni melakukan koordinasi dengan krama desa melalui paruman; mengumpulkan berbagai bukti terkait asal-usul tanah yang disengketakan; melakukan kewajiban terhadap pemilik tanah sengketa yang dinyatakan ceput atau tidak memiliki keturunan; melakukan koordinasi dengan Majelis Madya Kabupaten Buleleng, pengemong pura desa setempat; dan melakukan pendaftaran hak milik kepada kantor BPN setempat.
\end{abstract}

Kata Kunci: Adat, Regulasi Pertanahan, Sengketa Tanah.

\begin{abstract}
The study aims to determine the factors underlying the occurrence of customary land dispute in the village and form alignments Kubutambahan regulation of land to indigenous peoples' rights, as well as participation in resolving disputes. The study uses a qualitative approach. The results showed that: 1) The causes of land disputes, are: The confusion of the family tree; process of land administration is less clear; lack of understanding of the system and customary inheritance pattern; and lack of public's understanding of the national land regulations, (2) The national regulatory alignments are: the legal protection of human rights and the cultural identity of indigenous peoples, including customary land rights; There is recognition
\end{abstract}


and respect of the village authority to regulate and manage the interests of local communities by origin and local customs; assertion that customary law basis agrarian statute, and the protection of rights to land Village People, (3) Pakraman participation in resolving disputes are: doing forum discussion with villagers wich is named Paruman, gather evidence about disputed land, undertake an obligation to the landowner who called ceput, having coordination with form of representation called Majelis Madya, customary village leader, and registering property rights to the land office (BPN).

Keywords: Indigenous, Regulation of Land, Land Disputes

\section{PENDAHULUAN}

Tanah merupakan unsur yang begitu penting dalam menopang kehidupan serta penghidupan manusia. Sayangnya keberadaan tanah tidak hanya sebagai faktor penunjang kemakmuran bangsa Indonesia semata, tetapi juga memiliki andil yang cukup besar sebagai sumber perselisihan atau konflik. Dengan semakin meningkatnya pertumbuhan penduduk, maka kebutuhan manusia akan tanah juga semakin meningkat. Di sisi lain, jumlah tanah yang tersedia semakin terbatas, sehingga dengan adanya dua antinomi ini tidak mustahil akan melahirkan konflik/persengketaan yang berobyek tanah (land conflicts) (Inten, 2010:1).

Pada umumnya motif dan latar belakang timbulnya berbagai konflik pertanahan antara lain (1) kurang tertibnya administrasi pertanahan di masa lampau, (2) Kondisi masyarakat yang semakin menyadari dan mengerti akan kepentingan dan haknya, (3) Iklim keterbukaan sebagai salah satu kebijakan yang digariskan pemerintah, (4) masih banyaknya tanah-tanah yang belum memiliki sertifikat, (5) tanah yang dikuasai oleh seseorang belum tentu kepemilikannya ada pada orang yang menempati, (6) proses pewarisan tanah tidak ditetapkan melalui mekanisme hukum, (7) masih adanya tanah yang penguasaannya secara komunal yang sewaktu-waktu dapat menyebabkan konflik, dan (8) adanya pihak-pihak yang menggunakan kesempatan untuk mencari keuntungan materil secara tidak wajar (Chomzah, 2003: 21). Kondisi ini memunculkan berbagai persoalan pertanahan, seperti sengketa proses penyertifikatan tanah, sengketa kepemilikan tanah, sengketa proses pewarisan tanah, usaha penggagalan eksekusi tanah, perlawanan putusan penegak hukum, bahkan sampai pada perlawanan eksekusi tanah yang dilakukan melalui adu fisik sebagaimana terjadi di beberapa daerah di Bali.

Kultur masyarakat Bali merupakan karakteristik yang membuat Bali memiliki keunikan tersendiri di mata dunia. Masyarakat Bali sejak zaman Mpu Kuturan mengenal sistem Kahyangan Tiga yang dalam kehidupan sosial diimplementasikan dalam wadah desa pakraman yang terbagi lagi dalam konsep banjar-banjar. Disamping sistem desa pakraman yang di dalamnya terdapat filosofi Tri Hita Karana (Parahyangan (Tuhan), Pawongan (manusia), Palemahan (alam)), masyarakat Bali juga mengenal adanya kegiatan ngayah yang dijalankan di setiap desa pakraman dan diatur dalam awig-awig desa adat setempat. Adanya konsep Padma Bhuana yang mengatur 
secara jelas fungsi-fungsi ruang di Bali juga menjadi keistimewaan tersendiri dalam kehidupan masyarakat Bali (Windari, 2011). Masyarakat Bali sebagai komunitas sosial yang sebagian besar penduduknya mengandalkan sektor pertanian dan pariwisata, memaknai tanah sebagai tempat dan ruang yang harus diharmoniskan dan di jaga sesuai dengan filosofi Tri Hita Karana (Windari, 2010). Untuk menjaga tetap utuh dan harmonisnya kondisi tanah, masyarakat Bali melakukan berbagai upacara untuk mengembalikan kesuburan dan kesucian tanah, seperti pemayuh gumi, upacara ngeresi gana, ngelukat pertiwi, mecaru dan lain sebagainya. Hal ini merupakan wujud penghargaan sekaligus pemaknaan fungsi dan kegunaan tanah bagi masyarakat Bali dan kelangsungan hidupnya (Suasthawan, 1987). Tak heran jika Bali menjadi salah satu daerah di Indonesia yang hingga saat ini tetap mempertahankan keberadaan tanah adat (komunal), seperti tanah Druwe Desa, tanah Laba Pura, tanah Pekarangan Desa, dan tanah Ayahan Desa.

Sayangnya fungsi tanah yang mengandung sifat "religio-magis", perlahan tapi pasti beralih menjadi fungsi ekonomi. Nilai sakral yang melekat pada tanah, kehilangan nilai kesakralannya. Paradigma berpikir masyarakat terhadap tanah menjadi sangat pragmatis. Sehingga, konsepsi tentang tanah bermetamorfosa menjadi terfokus pada nilai-nilai materialistik-kapitalistik semata (Sarad, 2000). Persoalan tanah merupakan akar substansial filosofis yang menentukan kesejatian eksistensial orang Bali. Pergeseran persepsi masyarakat terhadap tanah, sangat potensial mendorong terjadinya perubahan sosial di dalam masyarakat Bali. Paradigma sosio-kultural masyarakat Bali terhadap makna tanah menjadi makin kompleks.

Dewasa ini sering terjadi berbagai kasus terkait tanah komunal akibat adanya kelemahan administrasi status kepemilikan tanah yang tidak disertifikatkan oleh masyarakat karena sudah dianggap dimiliki secara sah sebagai hak masyarakat adat, seperti kasus perebutan tanah adat di Klungkung dan di Kintamani Bangli dengan pihak puri yang mengklaim kepemilikan tanah tersebut berdasarkan adanya sertifikat hak milik.

Secara yuridis formal, sertifikat merupakan bukti otentik kepemilikan atas tanah yang harus dimiliki oleh semua masyarakat yang memiliki tanah di Negara Kesatuan Republik Indonesia sebagaimana amanat Undang-Undang Nomor 5 Tahun 1960 tentang Pokokpokok Agraria (UUPA). UUPA selaku regulasi pertanahan nasional mewajibkan setiap warga negara Indonesia yang memiliki tanah untuk menyertifikatkan tanahnya. Ketentuan ini dimaksudkan agar tidak terjadi persengketaan dan konflik kepemilikan tanah yang tidak bersandar pada hukum nasional yang berlaku (UUPA No. 5 Tahun 1960).

Seiring perkembangan zaman, isu globalisasi menyebabkan terjadinya persaingan global yang ditandai dengan berbagai pemikiran-pemikiran materialistik dan individualistik, ditambah dengan keinginan-keinginan untuk tetap eksis secara ekonomi finansial, hal ini menyebabkan orang melakukan berbagai macam cara untuk memperoleh keuntungan pribadi. Salah satu sektor yang menjadi incaran kaum materialistik

Jurnal IImu Sosial dan Humaniora | 330 
individualis adalah pertanahan. Sertifikat sebagai bukti kepemilikan tanah seringkali digunakan sebagai alat bagi pihak-pihak tertentu guna melegalkan tindakan pengambilalihan hak milik atas tanah, tak terkecuali tanah hak adat seperti tanah druwe desa yang berujung konflik sebagaimana terjadi di desa Kubutambahan.

Dengan pengawalan yang begitu intens dari desa pakraman setempat dan pengaruh regulasi pertanahan nasional, sengketa tanah adat yang terjadi di desa Kubutambahan akhirnya terselesaikan melalui jalur litigasi (pengadilan) yang berujung pada kemenangan masyarakat adat. Hal ini merupakan fenomena hukum yang cukup unik mengingat hampir sebagian besar sengketa pertanahan yang berkaitan dengan tanah adat melawan tanah perorangan seringkali dimenangkan oleh pihak perorangan/ pribadi. Berpijak dari kondisi tersebut diatas, penting kiranya dilakukan penelitian terkait keberpihakan regulasi pertanahan serta peranan desa pakraman dalam penyelesaian sengketa tanah adat guna membantu masyarakat adat mempertahankan hak kepemilikan tanah adat yang dewasa ini menjadi incaran berbagai pihak dengan memanfaatkan kelemahan masyarakat adat terkait bukti kepemilikan hak atas tanah adat.

Penelitian bertujuan untuk mengetahui faktor-faktor yang melatarbelakangi terjadinya sengketa tanah adat di Desa Kubutambahan, bentuk keberpihakan regulasi pertanahan terhadap hak masyarakat adat; dan peran serta desa pakraman dalam mengatasi sengketa tanah adat di Desa Kubutambahan
Manfaat yang diperoleh dari penelitian ini adalah : Bagi masyarakat Desa Kubutambahan, hasil penelitian ini dapat menjadi salah satu pedoman dalam memformulasikan kebijakan pengelolaan dan penyelesaian sengketa pertanahan sehingga integrasi sosial tetap terjaga; Bagi Desa Pakraman, hasil penelitian ini dapat dijadikan model dalam memperjuangkan hak masyarakat adat serta mempertahankan keberadaan tanah-tanah adat dari berbagai konflik pertanahan; Bagi Pemerintah Kabupaten Buleleng, temuan penelitian ini dapat dijadikan model dalam menyelesaikan konflik yang terjadi di tingkat lokal, serta menjadi acuan dalam menyusun Perda tentang penguasaan dan pengelolaan tanah hak adat di Kabupaten Buleleng; Bagi peneliti sejenis, temuan penelitian ini dapat dijadikan sebagai salah satu bahan untuk mengkaji permasalahan terkait keberadaan tanah-tanah hak adat pada masyarakat Buleleng dan Bali pada umumnya.

\section{METODE PENELITIAN}

Berdasarkan fokus masalah penelitian yang telah diuraikan di atas, maka penelitian ini secara metodologis menggunakan pendekatan kualitatif (Sugiyono, 2006). Rasional pemilihan pendekatan tersebut karena untuk menggali dan memformulasikan faktorfaktor yang melatarbelakangi terjadinya sengketa tanah adat di desa Kubutambahan, bentuk penyelesaian sengketa atas tanah menurut regulasi pertanahan nasional; dan peran serta Desa Pakraman dalam mengatasi sengketa tanah adat di Desa Kubutambahan. Oleh karena itu, penelitian ini akan dimulai dari observasi awal untuk menentukan urgensi

Jurnal IImu Sosial dan Humaniora | 331 
masalah, melakukan wawancara secara mendalam, memfokuskan data dan mendeskripsikan data sesuai dengan alur penelitian kualitatif

Analisis data dalam penelitian ini dapat dijabarkan sebagai berikut (Miles dan Hubermen. 1992): 1) Katagorisasi dan Kodifikasi, pada tahap ini data yang telah terjaring akan ditulis dalam kartu data dan kemudian dikatagorisasikan dengan memberi kode-kode tertentu berdasarkan jenis dan bentuknya. Katagorisasi dan Kodifikasi data dilakukan dengan tujuan untuk memudahkan interpretasi dan verifikasi data berikutnya. 2) Reduksi Data, dalam tahap ini data yang telah terkumpul akan direduksi, dirangkum, dan dipilih hal-hal yang penting dan berhubungan dengan kajian penelitian. Data yang tidak berhubungan dengan kajian penelitian akan dieliminir untuk dilakukan analisis data berikutnya, sehingga memudahkan penarikan kesimpulan dan verifikasi data. 3) Penyajian dan Klasifikasi Data, untuk dapat melihat gambaran data secara menyeluruh, maka akan dilakukan klasifikasi dengan menggunakan beberapa matrik data, kemudian dideskripsikan secara rinci. Klasifikasi ini dilakukan dengan menggunakan kode yang telah digunakan pada tahap sebelumnya. 4) Penarikan Kesimpulan dan Verifikasi, pada dasarnya dalam penelitian naturalistik pengambilan kesimpulan telah dilakukan sejak awal penelitian, namun terus dikembangkan dan di verifikasi selama berlangsungnya penelitian. Dalam verifikasi ini, peneliti berusaha mencari data baru atau memperdalam penelitian. $\mathrm{Hal}$ ini dilakukan untuk merumuskan hipotesis- hipotesis penelitian sampai terbentuknya hipotesis akhir penelitian.

\section{HASIL DAN PEMBAHASAN}

Desa Kubutambahan merupakan salah satu Desa Pakraman yang memiliki $\pm 460 \mathrm{Ha}$ tanah Laba Pura Desa dan terluas bila dibandingkan dengan desa pakraman lainnya. Sebagaimana dipaparkan oleh bapak Jro Pasek Ketut Warkadea selaku Klian desa adat Kubutambahan (sekaligus sebagai Kepala Dinas Pariwisata Kabupaten Buleleng) bahwa Desa Adat Kubutambahan telah diakui keberadaannya mulai tahun 1711 yang ditandai dengan "awig-awig Wong Sakrama ring Kubutambahan". Seiring perkembangan waktu, dimana nilai ekonomis tanah semakin meningkat di wilayah Bali akibat meningkatnya pertumbuhan sektor pariwisata maka tanah laba pura yang telah dimiliki secara turun temurun oleh desa pakraman Kubutambahan mulai diterpa berbagai konflik pengklaiman tanah oleh orang perorangan.

Salah satu sengketa tanah adat di Desa Kubutambahan yang begitu besar dan menjadi perhatian publik maupun para praktisi hukum serta tokoh masyarakat adat adalah sengketa tanah Duwe (Milik) Pura Desa Kubutambahan dengan Pihak Gede Kastawan Cs. Penguasa fisik tanah-tanah Adat (Tanah Laba Pura Adat Kubutambahan) telah dikuasai secara turun-temurun, sejak saat adanya klasiran 1 tahun 1942, telah terdaftar menjadi tanah Duwe Pura Desa. Lebih-lebih tahun 2001 disertifikasikan melalaui P3HT Badan Pertanahan Nasional Kabupaten Buleleng, berhasil menyertifikasikan seluas tanah 415 Ha Laba Pura Tanah

Jurnal IImu Sosial dan Humaniora | 332 
Cecamputan Yang Menjadi Laba Pura, $35 \mathrm{Ha}$. Berdasarkan Paruman Desa tanggal 15 Agustus 1970 telah menetapkan Almarhum I Gede Wira selaku pemilik tanah tidak memiliki keturunan (ceput) sehingga mengacu pada awig-awig desa adat Kubutambahan (Pawos 8b awig-awig Wong Sakrama ring Kubutambahan Tahun 1711) maka tanah tersebut akan manjing atau kembali menjadi tanah duwe pura desa.

Permasalahan muncul setelah adanya gugatan yang diajukan ke Pengadilan Negeri Singaraja pada tanggal 12 Oktober 2000 dari I Gede Kastawan anak dari Nyoman Tileh, atas dasar silsilah yang dibuat oleh Gede Kastawan dan ditandatangani oleh Made Ngadeg selaku Kepala Desa, tanpa diketahui/ disahkan oleh Penghulu Desa Adat/Bendesa terhadap silsilah tersebut. Dalam gugatannya, Kastawan menyatakan bahwa dirinya merupakan ahli waris dari I Gede Wira (alm) dan segala kekayaan/tanah-tanah tersebut berhak diwarisi kepada dirinya. Dalam peta rincik Desa Kubutambahan, leluhurnya Made Pas (Kastawan Cs.) tercatat atas nama Pan Sandat dan bukan atas nama I Gede Wira, hal ini menunjukkan bahwa sumber tanah/warisan I Gede Wira berasal dari leluhur yang mengangkatnya yang bernama I Putu Gigi Putih, bukan berasal dari leluhurnya Kastawan (Pan Sandat).

Sengketa tanah adat tersebut selanjutnya mengalami proses hukum diawali dengan proses di Pengadilan Negeri yang dimenangkan oleh pihak Gede Kastawan berdasarkan Putusan Pengadilan Negeri Singaraja Nomor 97/Pdt.G/200/PN Sgr, dilanjutkan Banding ke Pengadilan Tinggi dimana
Pengadilan Tinggi menolak putusan Pengadilan Negeri serta memenangkan pihak Desa Adat berdasarkan Putusan Pengadilan Tinggi Nomor 228/Pdt/2001/PT.Dps. Proses persidangan kemudian dilanjutkan Kasasi ke Mahkamah Agung yang dimenangkan oleh pihak Kastawan berdasarkan Putusan MA. RI No.2946 $\mathrm{K} / \mathrm{Pdt} / 2002$. Dari keputusan Mahkamah Agung yang mempunyai kekuatan hukum tetap di lanjutkan dengan PK (peninjauan kembali) yang diajukan oleh bapak Jro Pasek Ketut Warkadea selaku perwakilan dari pihak desa pakraman Kubutambahan dan berdasarkan putusan PK Nomor 1778 PK/Pdt/2006 maka tanah sengketa berhasil dimiliki kembali oleh desa pakraman Kubutambahan.

Menurut penuturan Kaur Pemerintahan Desa Kubutambahan bapak Gede Widiawan dan Kaur Pembangunan Desa Kubutambahan bapak I Made Wijana, pada tahun 2005 disaat proses perkara masuk dalam tahap PK, pihak Pengadilan Negeri Singaraja memaksakan dilakukannya eksekusi tanah sengketa tersebut, sehingga terjadi pergolakan menentang/ menolak eksekusi pada tanggal 28 Nopember 2005 yang dilakukan serempak oleh masyarakat Desa Kubutambahan dengan cara memblokir jalan menuju desa Kubutambahan.

Berdasarkan keterangan dari kepala desa Kubutambahan yakni bapak Ketut Sandirat dan krama desa adat Kubutambahan, bahwa sengketa tanah adat yang terjadi di desa Kubutambahan dipicu oleh berbagai hal, yaitu :
1. Adanya kesimpangsiuran silsilah keluarga

Jurnal IImu Sosial dan Humaniora | 333 
2. Kurangnya pemahaman akan sistem serta pola pewarisan adat

3. Keberadaan data lama yang masih diragukan keasliannya oleh sebagian orang.

Hal senada juga disampaikan oleh bapak Jro Pasek Ketut Warkadea selaku klian desa adat Kubutambahan, menurut beliau faktor-faktor yang menyebabkan terjadinya sengketa tanah adat di desa adat Kubutambahan antara lain:

1. Proses administrasi pertanahan yang kurang jelas;

2. Kurangnya pemahaman masyarakat tentang hak waris adat

3. Kurangnya pemahaman masyarakat tentang regulasi pertanahan nasional.

Timbulnya perbedaan silsilah keluarga pewaris, antara yang dibuat oleh desa adat dengan orang perorangan secara pribadi menjadi faktor penyebab terjadinya konflik pertanahan di desa adat Kubutambahan. Mengacu pada sengketa tanah adat yang terjadi di desa Kubutambahan, anak perempuan dari I Gede Putu Gigi Putih (pemilik awal tanah sengketa) memiliki seorang anak bernama I Gede Wira, setelah anak perempuannya bercerai kemudian I Gede Wira diangkat sentana oleh kakeknya sendiri yaitu I Gede Putu Gigi Putih dan disaksikan oleh krama Desa Linggih. Selanjutnya pada saat pengklasiran tahun 1942, tanah milik I Gede Putu Gigi Putih dimasukkan atas nama I Gede Wira dalam SPPT. Karena adanya pemahaman yang parsial terhadap silsilah keluarga ditambah lagi proses perumusan silsilah yang dilakukan secara perorangan dan tidak melibatkan para Penghulu Desa Adat/ Tetua desa adat Kubutambahan menyebabkan terjadi kesalahpahaman dalam menentukan ahli waris.
Dalam sistem pewarisan di Bali telah ditentukan bahwa yang berhak mewaris adalah keturunan Purusa, yaitu keturunan laki-laki garis menyamping sampai derajat kelima, dan apabila pewaris tidak memiliki keturunan (ceput) dan tidak meninggalkan ahli waris maka berdasarkan hukum adat Bali, status seluruh harta peninggalan keduanya harus ditentukan oleh desa adat setempat. Dalam konflik pertanahan yang terjadi di Desa Kubutambahan, pemahaman akan sistem pewarisan inilah yang masih dirasa kurang.

Proses administrasi pertanahan yang kurang jelas pada masa lalu juga menjadi sumber terjadinya konflik pertanahan. Bukti kepemilikan tanah seringkali hanya didasarkan pada surat pembayaran pajak sebagai produk kantor PBB/ IPEDA yang pada prinsipnya hanya berfungsis ebagai fiscal bilyet semata dan tidak bisa dinyatakan sebagai bukti otentik kepemilikan tanah sebagaimana produk sertifikat hak atas tanah yang dikeluarkan oleh BPN. Disamping itu, masih kurangnya pemahaman masyarakat akan ketentuan atau regulasi nasional di bidang pertanahan yang mengatur tentang hak tanah masyarakat adat serta aturan terkait penguasaan tanah yang ditelantarkan oleh pemilik atau ahli warisnya dalam jangka waktu 20 tahun.

Dalam konstitusi negara kita yakni UUD 1945 pasal 18 B ayat (2) disebutkan bahwa Negara mengakui dan menghormati kesatuan - kesatuan masyarakat hukum adat beserta hak-hak tradisionalnya. Penghormatan terhadap hak masyarakat adat juga tertuang dalam pasal 28 I ayat (3) yang menyatakan bahwa identitas budaya dan hak masyarakat tradisional dihormati 
selaras dengan perkembangan jaman dan peradaban. Merujuk pada ketentuan dasar inilah terlihat jelas adanya pengakuan dan penghormatan serta perlindungan terhadap hak masyarakat tradisional termasuk di dalamnya hak atas tanah masyarakat adat.

Keberpihakan regulasi terhadap hak masyarakat adat dapat dijabarkan lebih lanjut sebagai berikut:

a. Pasal 6 UU No. 39 tahun 1999 tentang Hak Asasi Manusia yang berbunyi:

(1)Dalam rangka penegakan hak asasi manusia, perbedaan dan kebutuhan dalam masyarakat hukum adat harus diperhatikan dan dilindungi oleh hukum, masyarakat dan pemerintah;

(2) Identitas budaya masyarakat hukum adat, termasuk hak atas tanah ulayat dilindungi, selaras dengan perkembangan jaman.

b. Undang-undang Nomor 32 tahun 2004 tentang Pemerintah Daerah. Pasal 1 ayat (12) menyatakan bahwa desa merupakan kesatuan masyarakat hukum yang memiliki batas wilayah yang berwenang mengatur dan mengurus kepentingan masyarakat setempat berdasarkan asal usul dan adat istiadat setempat yang diakui dan dihormati dalam sistem pemerintahan NKRI.

C. Undang-undang Nomor 5 tahun 1960 tentang Pokok-pokok Agraria (UUPA).

(1)Pasal 5 menyebutkan bahwa hukum agraria yang berlaku atas bumi, air dan ruang angkasa adalah hukum adat, sepanjang tidak bertentangan dengan kepentingan nasional.

(2) Penjelasan pasal 5 dan penjelasan umum II (1) UUPA berisi penegasan bahwa hukum adat merupakan hukum asli Indonesia yang dijadikan dasar hukum agraria.

(3)Pasal $21 \quad$ UUPA ayat (2) menyatakan bahwa pemerintah menetapkan badan-badan hukum yang dapat mempunyai hak milik atas tanah.

(4)Pasal 49 ayat (1) beserta penjelasannya yang menyatakan bahwa hak milik badan-badan keagamaan dan sosial sepanjang dipergunakan untuk usaha dalam bidang keagamaan dan sosial diakui dan dilindungi. Berdasarkan pasal ini secara tegas telah memberikan perlindungan dan pengakuan terhadap hak milik atas tanah badan-badan keagamaan termasuk hak Desa Adat.

d. Peraturan Pemerintah Nomor 38 tahun 1963 tentang Penunjukan Badan-badan Hukum yang dapat Mempunyai Hak Milik atas Tanah, yang salah satunya adalah Badanbadan Keagamaan (termasuk Desa Adat).

e. Peraturan Pemerintah Nomor 24 tahun 1997 tentang Pendaftaran Tanah jo. Peraturan Menteri Negara Agraria/Kepala BPN Nomor 3 tahun 1997, dalam pasal 76 ayat (3) mengintrodusir berlakunya lembaga verjaring (daluwarsa) dalam tatanan hukum dan sistem hukum pertanahan di Indonesia, dimana penguasaan fisik atas sebidang tanah selama 20 tahun terus menerus dan didasarkan pada itikad baik serta tidak dipermasalahkan oleh masyarakat hukum adat maka dapat dilakukan proses pendaftaran hak atas tanah tersebut. Hal ini tentunya akan 
membantu desa adat dalam pengurusan hak milik atas tanah, mengingat kepengurusan tanah adat oleh masyarakat adat dilakukan secara turun temurun bahkan seringkali lebih dari 20 tahun.

f. Perda Nomor 6 tahun 1986 tentang Desa Adat yang telah diganti dengan Perda Nomor 3 tahun 2001, dan diubah dengan Perda Nomor 3 tahun 2003 tentang Desa Pakraman.

(1) Pasal 1 butir 4, menyatakan bahwa desa pakraman adalah kesatuan masyarakat hukum adat di propinsi Bali yang memiliki wilayah tertentu dan harta kekayaan sendiri serta berhak mengurus rumah tangganya sendiri

(2) Pasal 9 menyebutkan bahwa harta kekayaan Desa Pakraman adalah kekayaan yang telah ada maupun yang akan ada, pengelolaan harta kekayaan dilakukan oleh prajuru desa sesuai awig-awig Desa Pakraman masing-masing, setiap pengalihan atau perubahan status harta kekayaan Desa Pakraman harus mendapat persetujuan

Paruman dan pengawasan atas harta kekayaan tersebut dilakukan oleh krama Desa Pakraman.

Berbagai regulasi pertanahan nasional pada prinsipnya memberikan pengakuan, perlindungan dan penghormatan terhadap hak-hak masyarakat adat. Hal ini didasarkan pada amanat UUD 1945 sebagai konstitusi atau dasar hukum dari bangsa Indonesia yang mengakui keberadaan masyarakat adat beserta hak dan kewajibannya. Dari penjabaran tersebut diatas terlihat bahwa regulasi pertanahan nasional memiliki keberpihakan terhadap hak-hak masyarakat adat, khususnya terkait kepemilikan hak atas tanah adat.

Dari berbagai teori konflik yang ada, kondisi yang dihadapi pada masyarakat desa Kubutambahan sesuai dengan teori konflik yakni kebutuhan manusia sebagai salah satu penyebab timbulnya suatu konflik dalam masyarakat. Konflik yang terjadi dapat bersifat open dan juga bersifat laten. Dalam hal pertanahan, sebagian besar konflik yang terjadi adalah bersifat open, dimana para pihak yang bersengketa cenderung mengalami kendala dalam melakukan penyelesaian secara kekeluargaan dan berujung pada penyelesaian sengketa melalui jalur litigasi (pengadilan). Demikian pula dengan konflik pertanahan yang terjadi di berbagai daerah termasuk di desa Kubutambahan Kabupaten Buleleng pada dasarnya muncul akibat adanya perebutan sumber daya yang dianggap berharga dan memiliki nilai ekonomis tinggi.

Faktor-faktor penyebab terjadinya sengketa tanah di desa Kubutambahan dipicu oleh berbagai hal, yaitu :

1. Adanya kesimpangsiuran silsilah keluarga;

2. Proses administrasi pertanahan yang kurang jelas;

3. Kurangnya pemahaman akan sistem serta pola pewarisan adat;

4. Keberadaan data lama yang masih diragukan keasliannya oleh sebagian orang;

5. Kurangnya pemahaman masyarakat tentang regulasi pertanahan nasional.

Keberadaan tanah laba pura maupun tanah adat lainnya di Bali memang semakin hari semakin mengkhawatirkan, mengingat lemahnya 
bukti kepemilikan tanah yang dimiliki oleh Desa Pakraman. Oleh karena itu diperlukan regulasi pertanahan yang berpihak terhadap hak masyarakat adat, khususnya hak di bidang pertanahan.

Untuk mengatasi terjadinya konflik pertanahan maka selain adanya keberpihakan regulasi pertanahan nasional terhadap pengakuan, perlindungan dan penghormatan akan hak-hak masyarakat adat, diperlukan juga adanya peran serta Desa Pakraman dalam mengawal dan menyelesaikan berbagai konflik pertanahan yang terjadi. Berdasarkan ketentuan pasal 5 Perda Propinsi Bali No.3 tahun 2001 tentang Desa Pakraman menyebutkan bahwa, Desa Pakraman memiliki tugas antara lain: (a) membuat peraturan desa (awigawig); (b) mengatur warga (krama) desa; (c) mengatur pengelolaan harta kekayaan desa; (d) bersama-sama pemerintah daerah melaksanakan pembangunan di segala bidang, terutama bidang kehidupan keagamaan, kebudayaan, dan kemasyarakatan; (e) membina dan mengembangkan nilai-nilai budaya Bali dalam rangka memperkaya, melestarikan, dan mengembangkan kebudayaan nasional pada umumnya dan kebudayaan daerah pada khususnya, berdasarkan prinsip parasparos, sagilik-saguluk, salunglungsabayantaka (musyawarah mufakat); dan (f) mengayomi krama desa. Selanjutnya dalam Pasal 6 menyebutkan kewenangan yang dimiliki oleh Desa Pakraman antara lain: (1) menyelesaikan sengketa tanah adat dan agama dalam lingkungan wilayahnya dengan tetap membina kerukunan dan toleransi antar krama desa sesuai awig-awig dan adat kebiasaan setempat; (2) turut serta menentukan setiap keputusan dalam pelaksanaan pembangunan yang ada di wilayahnya terutama yang berkaitan dengan konsepsi Tri Hita Karana; dan (3) melakukan perbuatan hukum di dalam dan di luar Desa Pakraman.

Adapun bentuk peran serta Desa Pakraman dalam mengatasi konflik pertanahan yang ada, antara lain:

a) Melakukan koordinasi dengan krama desa serta melakukan paruman terkait persetujuan dilanjutkannya sengketa pertanahan tersebut ke jalur hukum (litigasi).

b) Mengumpulkan berbagai bukti terkait asal-usul tanah yang disengketakan yang mendukung kepemilikan Desa Pakraman atas tanah tersebut.

c) Mengumpulkan bukti terkait kewajiban yang telah dilakukan oleh Desa Pakraman terhadap pemilik tanah sengketa yang dinyatakan ceput atau tidak memiliki keturunan. Adapun bentuk tanggung jawab yang dimaksud adalah mengurus segala keperluan pemakaman hingga upacara Ngaben dan upacara keagamaan lainnya.

d) Meminta kepada Majelis Madya untuk segera membuatkan surat pernyataan yang isinya menyatakan bahwa hubungan tunggal kawitan saja tidak menyebabkan seseorang memiliki hubungan waris mewaris secara langsung.

e) Melakukan koordinasi dengan pengemong pura desa yang dituangkan dalam dokumen berupa surat atas nama pengemong pura bahwa menyatakan keberatan dan menolak segala bentuk dan perbuatan hukum yang bermaksud memindahkan/ mengalihkan hak milik tanah-tanah pura desa (Laba Pura).

Jurnal IImu Sosial dan Humaniora | 337 
f) Mencermati regulasi pertanahan nasional, dalam hal ini khususnya PP No. 24 tahun 1997, jo. pasal 76 ayat (3) Peraturan Menteri Negara Agraria/Kepala BPN No. Tahun 1997, jo. pasal 4 dan pasal 5 ayat (2) PP No 38 tahun 1963, jo. SK Menteri Dalam Negeri No. 556/DJA/1986, jo. pasal 25 ayat (2) dan pasal 49 UUPA, dimana tanah sengketa telah dikuasai secara fisik oleh Pura Desa lebih dari 20 tahun (telah verjaring) sehingga desa berhak untuk mendaftarkan tanah tersebut sebagai tanah hak milik desa.

g) Mendaftarkan kepada kantor BPN setempat untuk memperoleh bukti kepemilikan hak atas tanah

h) Mencermati keberadaan awig-awig selaku hukum di masyarakat adat khususnya terkait hukum adat Bali bagi kramanya yang meninggal dan tidak memiliki keturunan (ceput), sebagai contoh dalam Pawos 8b awig-awig Wong Sakrama ring Kubutambahan Tahun 1711 disebutkan bahwa tanah tersebut akan manjing atau kembali menjadi tanah duwe pura desa.

i) Melakukan konsultasi secara intens dengan para pakar hukum khususnya dalam bidang pertanahan.

Melalui keberpihakan regulasi pertanahan serta komitmen bersama dari seluruh masyarakat dan berbagai elemen dalam suatu tatanan Desa Pakraman maka keberlangsungan dan kebertahanan hak-hak masyarakat adat khususnya pertanahan dapat terus ditingkatkan. Desa Pakraman memiliki peranan yang sangat penting sebagaimana amanat Perda No.3 Tahun 2001 yang diubah dengan Perda No.3 tahun 2003 tentang Desa Pakraman dalam hal meminimalisir terjadinya konflik di masyarakat, dalam Pasal 6 secara tegas telah disebutkan bahwa kewenangan yang dimiliki oleh Desa Pakraman salah satunya adalah menyelesaikan sengketa tanah adat dan agama dalam lingkungan wilayahnya dengan tetap membina kerukunan dan toleransi antar krama desa sesuai awigawig dan adat kebiasaan setempat.

\section{PENUTUP}

Faktor-faktor penyebab terjadinya sengketa tanah di desa Kubutambahan dipicu oleh berbagai hal, yaitu: (a) Adanya kesimpangsiuran silsilah keluarga; (b) Proses administrasi pertanahan yang kurang jelas; (c) Kurangnya pemahaman akan sistem serta pola pewarisan adat; (d) Keberadaan data lama yang masih diragukan keasliannya oleh sebagian orang; dan (e) Kurangnya pemahaman masyarakat tentang regulasi pertanahan nasional.

Bentuk keberpihakan regulasi nasional terhadap hak masyarakat adat yaitu: (a) Adanya perlindungan hukum dan hak asasi manusia terhadap Identitas budaya masyarakat hukum adat, termasuk hak atas tanah ulayat (Pasal 6 UU No. 39 tahun 1999 tentang HAM); (b) Adanya pengakuan dan penghormatan wewenang desa dalam mengatur dan mengurus kepentingan masyarakat setempat berdasarkan asal usul dan adat istiadat setempat (UU No.32 tahun 2004 tentang Pemerintah Daerah); (c) Penegasan bahwa hukum adat dijadikan dasar berlakunya hukum agraria, dan adanya perlindungan serta pengakuan terhadap hak milik atas tanah Desa Adat. (Pasal 5 dan pasal 49 ayat

Jurnal IImu Sosial dan Humaniora| 338 
(1) UU No.5 tahun 1960 tentang Pokokpokok Agraria); (d) PP No.38 tahun 1963 tentang Penunjukan Badan-badan Hukum yang dapat Mempunyai Hak Milik atas Tanah, yang salah satunya adalah Badan-badan Keagamaan termasuk Desa Adat; (e) Adanya lembaga verjaring, penguasaan fisik atas sebidang tanah selama 20 tahun dan didasarkan pada itikad baik serta tidak dipermasalahkan oleh masyarakat hukum adat maka dapat dilakukan proses pendaftaran hak atas tanah (PP No.24 tahun 1997 tentang Pendaftaran Tanah); dan (f) Adanya pengakuan terhadap hak pengelolaan kekayaan dalam Desa Pakraman yang dilakukan oleh prajuru desa sesuai awig-awig Desa Pakraman masing-masing (Pasal 1 dan pasal 9 Perda Nomor 3 tahun 2001 yang diubah dengan Perda Nomor 3 tahun 2003 tentang Desa Pakraman).

Bentuk peran serta Desa Pakraman dalam mengatasi konflik pertanahan yang ada, antara lain: (a) Melakukan koordinasi dengan krama desa melalui paruman; (b) Mengumpulkan berbagai bukti terkait asal-usul tanah yang disengketakan: (c) Melakukan kewajiban terhadap pemilik tanah sengketa yang dinyatakan ceput atau tidak memiliki keturunan; (d) Melakukan koordinasi dengan Majelis Madya Kabupaten Buleleng; (e) Melakukan koordinasi dengan pengemong pura desa setempat; (f) Mencermati regulasi pertanahan nasional; (g) Melakukan pendaftaran hak milik kepada kantor BPN setempat; (h) Mencermati awig-awig selaku hukum di masyarakat adat Bali terkait tanah ceput sebagai contoh dalam Pawos 8b awigawig Wong Sakrama ring Kubutambahan Tahun 1711 disebutkan bahwa tanah tersebut akan manjing atau kembali menjadi tanah duwe pura desa; dan (i) Melakukan konsultasi secara intens dengan para pakar hukum khususnya dalam bidang pertanahan.

Bagi Desa Adat Kubutambahan diharapkan mampu menjadi fasilitator dalam memberikan pemahaman tentang sistem dan pola pewarisan adat serta regulasi pertanahan nasional bagi masyarakat setempat. Disamping itu, perlu dilakukan dokumentasi dan validasi kepemilikan tanah Laba Pura maupun jenis tanah adat lainnya untuk mengantisipasi terjadinya konflik pertanahan dengan masyarakat desa setempat. Bagi masyarakat Desa Kubutambahan, hendaknya mematuhi dan memahami aturan hukum yang berlaku, baik hukum adat mapun hukum nasional, termasuk menyelesaikan permasalahan pertanahan secara kekeluargaan.

\section{DAFTAR PUSTAKA}

Ardjana, I Gusti Bagus Ngurah, 1980, Pura Meduwe Karang, Proyek Sasana Budaya Bali: Direktorat Jenderal Kebudayaan Departemen Pendidikan dan Kebudayaan.

Awig-awig Desa Pakraman Kubutambahan Tahun 1711, di himpun oleh Jero Pasek I Ketut Warkadea Klian Desa Pakraman Kubutambahan.

Chomzah, Ali Achmad, 2003, Hukum Pertanahan, Jakarta: Prestasi Pustaka.

Dharmayudha, Suasthawa, 1994, Filsafat Adat Bali, Denpasar: Upada Sastra.

Jurnal IImu Sosial dan Humaniora | 339 
Harsono, Budi, 2008, Hukum Agraria Indonesia, Jilid 1: Hukum Tanah Nasional, Jakarta: Penerbit Djambatan.

Inten, I Gede, 2010, Buku Ajar Hukum Agraria I, Singaraja: Undiksha.

Miles, M.B dan A.M. Hubermen, 1992, Analisis Data Kualitatif Buku Sumber tentang Metode-metode Baru. (Tjetjep Rohendi Rohidi Penerjemah), Jakarta: UI Press.

SARAD, No. 10 Tahun I Oktober (2000), Tanah Bali Tanpa Natah, Denpasar: Yayasan Gumi Bali.

Suasthawa, 1987, Status dan Fungsi Tanah Adat Bali Setelah Berlakunya UUPA, Denpasar: CV. Kayu Mas.

Sadia, Wayan, 2001, Pedoman Penyusunan Proposal Penelitian, Singaraja: Lembaga Penelitian IKIP Negeri Singaraja.

Sugiyono, 2006, Metode Penelitian Kuantitatif kualitatif dan $R \& D$, Bandung: ALFABETA.

Undang-undang Nomor 5 Tahun 1960 Tentang Peraturan Dasar PokokPokok Agraria (Lembaran Negara 1960-104).

Warkadea, Jero Pasek Ketut, 2007, "Tinjauan Kasus Tanah Duwen
MPLA Daerah Tingkat I Bali, 1998, Hasilhasil Pesamuhan Pembina Desa Adat Daerah Tingkat I Bali tanggal 20 Maret 1998, Denpasar: MPLA.

Peraturan Daerah Nomor 3 Tahun 2001 tentang Desa Pakraman/Adat.

Rimbawa, Made, 2008, "Status Hak Desa Pakraman Sebagai Subyek Hak Milik Atas Tanah, Singaraja: Majelis Madya Desa Pakraman Kabupaten Buleleng.

Pura Desa Kubutambahan dengan Pihak Gede Kastawan Cs", Singaraja: Penghulu Desa Pakraman Kubutambahan.

Windari, Ratna Artha, 2010, "Dilema Hukum Penyertifikatan Tanah Ayahan Desa di Bali (Studi Kasus Konflik Adat Tanah Ayahan Desa di Desa Adat Panglipuran)", Jurnal IKA Vol.8, No.2, September 2010, Singaraja: Ikatan Keluarga Alumni Undiksha.

, 2011, "Korelasi Yuridis Rencana Tata Ruang Wilayah Propinsi (RTRWP) Terhadap Keajegan Alam Bali", Jurnal Media Komunikasi FIS, Edisi Khusus PPKn Vol.10, No.3, Desember 2011, Singaraja: Fakultas IImu Sosial Undiksha. 